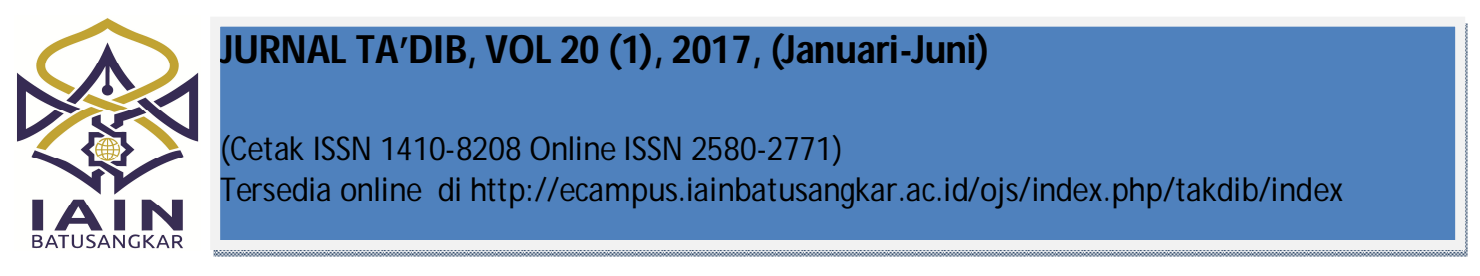

\title{
Development of Mobile Learning Based- Interactive Multimedia in Programming Language Class at STAIN Batusangkar
}

\author{
Lita Sari Muchlis*) \\ Institut Agama Islam Negeri Batusangkar, \\ Sumatera Barat, Indonesia \\ E-mail: litamuchlis@gmail.com
}

Fitra Kasma Putra*

Institut Agama Islam Negeri Batusangkar, Sumatera Barat, Indonesia

E-mail: Fitra_stmik@yahoo.com

\begin{abstract}
Abstrak: This study aims at developing mobile learning-based interactive media in programming language I subject. This research uses the ADDIE model, in which the proposed instructional media are tested to students of Informatics Management study program at STAIN Batusangkar, particularly in Programming Language course I. Data collection was done by distributing the questionnaires. At first, the need analysis was conducted by observing the related phenomena and previous research. Next, after the designing stage, the product was validated by three experts. As the result, the product, in terms of content, was 81,05 categorised very valid, besides in terms of design, it was valid with 85,6 score. In terms of practicality, the product was applied to the students. The result shows that the product was practical to use in Progamming Language course I. In order to find out its effectivity, the product was tested twice, before and after treatment. The mean score of post-test result was higher t "test" $0,001<0,05$ than that of the pre-rest. Based on data analysis both design validation by experts and test results of the students, then the interactive online learning media is recommended to be developed for STAIN Batusangkar students.
\end{abstract}

Keyword: Development, Interactive media, Mobile learning.

\section{PENDAHULUAN}

Perkembangan Teknologi dan Komunikasi (TIK) terus bekembang dengan cepat, penomena tersebut mengakibatkan banyak persaingan dalam berbagai bidang kehidupan, salah satunya akan berdampat pada dunia pendidikan. Perguruan Tinggi adalah faktor yang sangat menentukan dalam rangka melahirkan kualitas lulus yang mempunyai kompetensi, karena proses pembelajaran, karena proses pembelajaran inilah yang menentukan arah tujuan pembelajaran dengan ditandai adanya perubahan prilaku baik menyangkut pengetahuan (kognitif), keterampilan (psikomotor) maupun yang menyangkut nilai dan sikap (afektif). Menurut Slameto (2010:54-71) mengemukan ada 2 faktor yang mempengaruhi hasil belajar yaitu: pertama faktor internal yang mencangkup jasmani, inlegensi, motivasi, perhatian, minat dan kesiapan,. Kedua faktor keluarga, masyarakat, metoda pembelajaran, kurikulum dan alat pembelajaran, sehingga dua faktor sangat mempengaruhi mahasiswa dalam meningkatkan kompetensinya dalam meraih pendidikan di Perguruan Tinggi.

Salah satu penggunaan teknologi informasi pada media pembelajara adalah berbasis mobile learning mengacu kepada penggunaan perangkat atau devais teknologi informasi/TI genggam dan bergerak seperti: PDA/Personal Digital Assisant, telepon seluler/handphone, laptop dan tablet PC, dalam perkembangan pembelajaran mobile learning dengan teknologi komunikasi bergerak merupakan bagian dari electronic learning sehingga, 
dengan sendirinya, juga merupakan bagian dari distance learning( Taryadi, 2010).

Mobile learning tidak dapat menggantikan proses belajar konvensional karena sifat dari mobile learning bukan untuk memahamkan sebuah konsep tetapi lebih cenderung untuk mengingatkan materi yang telah didapat pada model konvesional dengan dapat mengunggah materi-mater pembelajaran tanpa batas waktu secara online sehingga memungkin pengguna menjadi aktif dan interaktif secara multimedia berbasis mobile learning (Hasyim, 2002,sutrino, 2005, Keegen 2010).

Dengan persoalanaan di atas merupakan tantangan tersendiri bagi para pengajar untuk mengembangkan metode pembelajaran yang dapat memotivasi mahasiswa agar dapat menikmati dan nyaman mengikuti mata kuliah bahasa pemrograman I sehingga mereka dapat menguasai materi dan dapat membuat produk berupa program komputer sederhana yang fungsional. Pengolahan sistem multimedia yang interaktif berbasis mobile dapat digunakan dalam pembelajaran bahasa pemrograman I sehingga materi ajar dan latihan dapat disusun sesuai dengan model perkembangan pengguna. Visualisasi yang berkaitan dengan gerak disebut animasi, sedangkan yang tidak bergerak dinamakan visualisasi (Sutrisno, 1993 dalam Mayub, 2005).

Matakuliah Bahasa permograman pada Prodi Manajemen Informatika di STAIN Batusangkar merupakan salah satu matakuliah yang bersyarat pada matakuliah di semester berikut, pada mata kuliah ini kompetensi dasar yaitu: mahasiswa mampu membuat dan menerapkan teori2 pemrograman untuk keperluan perancangan program, namun pada implementasi dilapangan didapat informasi melalui wawancara dan survei bahwa mata kuliah ini kurangnya motivasi mahasiswa dalam melaksanakan proses pembelajaran masih rendah karena pemahaman tentang programming masih rendah, serta kurang kreatifitasyang dikuasai mahasiswa pada matakuliah Bahasa Pemograman I.Matakuliah Bahasa Pemrograman I.

Sehingga perlu pengembangan untuk meningkatkan kompetensi dengan media pemebalajaran interaktif berbasis mobile learrning pada matakuliah bahasa permograman pada Jurusan Manajemen Informatika IAIN Batusangkar sistem pendidikan yang berjalan pada saat ini yaitu tatap muka antara mahasiswa dengan dosen memang sudah berjalan dengan baik walaupun e-campus sebagai media $e$ learning namun perlu dikembangkan media yang lebih multimedia interaktif berbasis mobile. Hal ini tentunya dapat dibuat lebih efisien dan terorganisasi. Konsultasi antara mahasiswa dengan dosen untuk membahas suatu bahan mata kuliah juga kadang tidak terpenuhi sebagai akibat sulitnya menemukan waktu yang tepat untuk untuk melakukan hal tersebut. Dalam hal lain, masalah yang sering muncul adalah keinginan beberapa mahasiswa untuk mengembangkan ilmunya namun kesulitan dalam mendapatkan sumbernya.

Untuk mengatasi masalah-masalah yang disebutkan di atas, maka perlu sebuah sistem pendukung untuk mendukung sistem pendidikan yang sudah ada. Sistem pendukung tersebut adalah multimedai interakif berbasis mobile. Dimana sistem multimedia interkatif dirancang E-learningberbasis mobile tersebut merupakan sebuah sistem pendidikan dengan menggunakan sebuah internet sebagai medianya. Dosen dapat meng-upload bahan mata kuliah maupun materi soal mata kuliah pada situs $e$ learningberbasis mobile. Mahasiswa dapat mempelajari bahan kuliah dari dosen yang bersangkutan dengan membuka situs $e$ learning tersebut.

Berdasarkan hasil observasi dan wawancara pada proses pembelajaran pada Bahasa Pemrograman I maka disimpulkan masalahan "Bagaimana model pembelajaran yang mulmedia interktif 
berbasisi mobile learning yang digunakan untuk meningkatkan kemampuan mahasiswa pada matakuliah Bahasa Pemrograman I ?

Dengan tujuan penelitian ini diharapkan dapat mengungkapkan: 1)Menghasilkan model multimedia interaktif berbasis mobile pada program di Jurusan Manajemen Informatika IAIN Batusangkar 2)Untuk melihat secara komprehensif validitas dan efektif model model multimedia interaktif berbasis mobilepada matakuliah bahasa pemrograman I pada program di Jurusan Manajemen Informatika IAIN Batusangkar.

Sehingga memberi manfaat dengan pengembangan model pembelajaran multimedia interkatif berbasis mobile learning pada matakuliah bahasa perograman I pada semester 3 pada Mahasiswa D3 Manajemen Informatika IAIN Batusangkar. Model pembelajaran multimedia interkatif berbasis mobile learning yang digunakan dapat membantu dosen dan mahasiswa pada proses pembelajaran, dosen akan berperan sebagai fasilitator dalam pemebalajaran.

\section{METODE PENELITIAN}

Model pengembangan yang digunakan oleh peneliti untuk mengembangkan EMobile berbasisandroidiniyaitumodel ADDIE. Pengembanganyang digunakan dalam penelitian iniadalah Model Desain PengembanganADDIE (Analysis-DesignDevelop-Implement- Evaluate)yang dipadu kan menurut langkah-langkah penelitian pengembanganyang direkomendasikan oleh Borg dan Galldengandasarpertimbanganbahwa model tersebutcocokuntuk mengembangkan aplikasi web progaramyang tepat sasaran, efektif dandinamisdansangatmembantu dalam pengembangan pembelajaran bagi guru. Model ADDIE (Analysis- Desain Develop-Implement- Evaluate)yang dikembangkanolehReiser danMollenda (1990an)

\section{HASIL DAN PEMBAHASAN}

\section{Teknik Analisis Data}

Teknik analisis data yang digunakan dalam penelitian ini adalah analisis data kualitatif yang mengikuti konsep yang diberikan oleh Miles dan Huberman dan juga analisis kuantitatif yang diolah secara statistik. Menurut analisis Miles dan Huberman, pemilihan rancangan analisis untuk penelitian didasarkan pada tiga komponen utama. Menurut Miles dan Huberman (1989) ketiga komponen pokok tersebut meliputi "reduksi data (data reduction), penyajian data (data display), dan penarikan kesimpulan (verifikasi)". Berikut adalah penjelasan ketiga

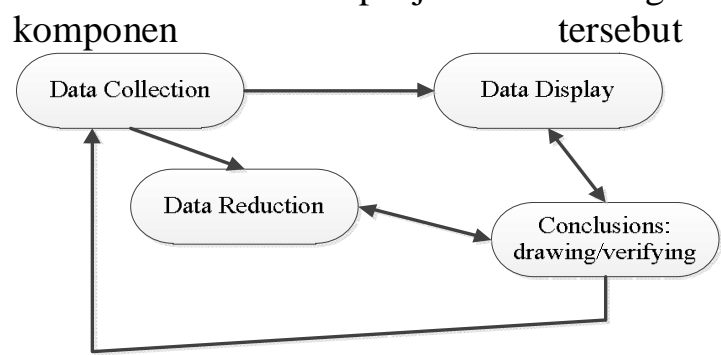
Gambar Model Analisis Interaktif
(Miles \& Huberman, (1992:20)

Proses penelitian diawali dengan pengumpulan data. Pengumpulan data merupakan proses pencarian data yang dilakukan dengan pengamatan dan wawancara. Setelah data dipilah-pilah, selanjutnya data disajikan dalam bentuk narasi kalimat yang disusun secara logis dan sistematis mengacu pada rumusan masalah.

Tahap terakhir adalah penarikan kesimpulan atau verifikasi data. Kegiatan dalam tahap akhir adalah mengambil kesimpulan atas pola-pola atau konfigurasi tertentu. Hasil simpulan perlu diverifikasi ulang agar dapat mengembangkan ketelitian hasil penelitian dengan skor ideal dan persentase tingkat capaian responden.

Data penelitian ini dianalisis dengan menggunakan Program SPSS versi 17.0. Analisis tersebut dilakukan dengan uji statistik $t$-test dependent (paired sample $t$ test) yaitu uji statistik yang digunakan 
untuk menganalisis data numerik, dilakukan pada subjek yang sama terhadap suatu pengaruh atau satu perlakuan. Dimana menurut Trihendradi (2009:115) "pengukuran dilakukan sebelum dan sesudah perlakuan". T-test dilakukan untuk mengetahui efektifitas produk ini terhadap peningkatan pembelajaran dengan mobile. Masing-masing data sebelum dan sesudah duperbandingkan dengan melihat perbedaan $t_{\text {hitung }}$ dengan $t_{\text {table }}$ dan $P$ Value dengan $\alpha(0,05)$.

\section{Penyajian Data Ujicoba}

Penelitian ini menghasilkan suatu produk berupa media pembelajaran multimedia interaktif secara online ( berbasis mobile) pada mata kuliah Bahasa Pemrograman I Proses pembuatan media pembelajaran multimedia interaktif berbasis mobile ini sesuai dengan proses pengembangan yaitu berdasarkan analisis kebutuhan media pembelajaran multimedia interaktif secara online dan uji validitas.

\section{Analisis kebutuhan Media Pembelajaran Multimedia Interaktif berbasis mobile}

Kuliah bahasa pemogramanan ini diberikan kepada mahasiswa D3 program studi manajemen informatika yang menggambil mata kuliah ini sebagai ilmu komputer. Perkuliahan ini dilakukan sebanyak 14 kali pertemuan kuliah tatap muka dan ada pratikum. Metode perkuliahan ini kombinasi antara ceramah, diskusi, dan latihan. Sedangkan pratikum dilaksanakan dengan metode tutorial dan latihan. Mahasiswa wajib mengikuti perkuliahan minimal 80 persen, dan pratikum 100 persen.

Penelitian dan pengumpulan informasi ini merupakan tahap awal dalam melakukan pengembangan media pembelajaran multimedia interaktif berbasis mobile. Pada tahap analisis kebutuhan media pembelajaran multimedia interaktif berbasis mobile ini, dilakukan beberapa analisis seperti dijelaskan dibawah ini:
1) Observasi

Observasi dilakukan pada jurusan ekonomi dan bisnis islam program studi manajemen informatika yang merupakan mahasiswa IAIN Batusangkar, mata kuliah Bahasa Pemrograman I di dapatkan masalah atau hambatan yang berasal dari mahasiswa dan dosen.

a. Analisis silabus

Materi yang dikembangkan dalam media pembelajaran multimedia interaktif berbasis mobile ini adalah standar kompetensi dan kompetensi dasar yang ada pada silabus mata perkuliahan bahasa pemograman I. Maka akan dibuat capaian matakuliah dalam media yang dikembangkan.

Learning Outcame yang terkait langsung dengan media pembelajaran multimedia interaktif berbasis mobile yang dikembangkan adalah mahasiswa mampu melakukan pemorgaman aplikasi data dengan menggunakan Visual Basic.net secara kreativitas.

b. Analisis buku referensi

Analisis buku refensi dilakukan untuk mengetahui materi materi yang akan disajikan dalam mulimedia interaktif berbasis mobile. Hal ini dilakukan untuk mengetahui cara penyajian yang tepat dalam media pembelajaran multimedia interaktif secara online.

\section{Pengembangan Produk Media Pembelajaran Multimedia Interaktif berbasis mobile.}

Hasil dari analisis kebutuhan digunakan untuk tahap selanjutnya yaitu tahap pengembangan. Pada tahap ini dilakukan langkah-langkah sebagai berikut:

a. Merancang prototype (rancangan awal)

Pada tahap ini dilakukan langkahlangkah sebagai berikut: 
1) Penyusunan kerangka dalam media pembelajaran multimedia interaktif berbasis mobile.

Penyusunan ini berupa desain tampilan multimedia interaktif berbasis mobile yang berisikan bagian intro, menu utama, dan bagian penutup. Petunjuk, berisi petunjuk media

2) Penentuan sistematika penyajian materi

Sistematika penyajian materi dalam multimedia interaktif secara online ini disesuaikan menurut silabus yang berlaku. Bahan-bahan yang diperlukan diambil dari seumbersumber yang relevan.

b. Perencanaan instrumen

Instrumen tersebut diantarannya angket validasi oleh ahli media dan ahli materi. Angket tersebut disebarkan kepada ahli ketika mereview media sebelum diujicobakan dilapangan. Instrumenintrumen tersebut divalidasi oleh para ahli sampai dinyatakan valid dan bisa mengukur.

c. Perencangan multimedia interaktif secara online dengan teknologi berbasis mobile

Pembuatan multimedia interaktif berbasis mobile ini menggunakan aplikasi Visual Basic.net. Berikut perancangan media pembelajaran multimedia interaktif dari program aplikasi Visual Basic.net.

1) Hasil rancangan program

Tampilan melalui aplikasi Visual Basic.net. Hasil ini dideskripsikan sesuai dengan file-file pembangun multimedia interaktif berbasis mobile.

2) Hasil rancangan Visual Basic.net

Proses perancangan multimedia interaktif berbasis mobile ini tidak sampai pada perancangan desain tampilan saja. Rancangan mulai dari Windows, Web, Cloud, Office, sampai pengembangan sharepoint. Sumber yang disediakan berupa dokumentasi, artikel, blog, dan video tutorial.
Tampilan awal atau halaman StarUp dapat dilihat sebagai berikut:

a. Membuat project baru

b. Membuka project

c. Project yang sudah dibuka sebelumnya.

3) Hasil revisi ahli

Data hasil penelitian dari ahli media dan ahli materi berupa saran, kritik, bentuk kesalahan beserta perbaikannya dapat diperinci sebagai, Untuk hasil revisi produk dapat dilihat pada lampiran 16

\section{Data Uji Validitas}

Pengambilan data validitas multimedia interaktif secara online sebagai media pembelajaran adalah dengan menggunakan angket. Dalam hal ini peneliti memberikan angket kepada lima orang ahli media dan ahli materi. Validator pertama melakukan validasi terhadap isi atau materi yang ada pada media. Aspek yang validasi meliputi silabus, rancangan pebelajaran semester (RPS) dan bahan ajar yang menggunakan dan aspek-aspke penting ketepatan dalam pengembangan silabus, rps, dan materi untuk kesesuaian dengan kurikulum yang digunakan.

Penilaian dari masing-masing aspek indikator yang diberikan oleh validator dihitung, dijumlahkan dan membuat persentase penilaian menurut aspek yang telah dibuat. Berikut tabel hasil validasi dari validator media.

Tabel. Hasil validasi isi atau materi media

\begin{tabular}{|l|l|l|l|l|l|}
\hline No & $\begin{array}{l}\text { Aspek } \\
\text { penila } \\
\text { ian }\end{array}$ & \multicolumn{3}{|c|}{$\begin{array}{l}\text { Persentase } \\
\text { penilaian }\end{array}$} & Kategori \\
\cline { 3 - 5 } & & V1 & V2 & $\begin{array}{l}\text { Rata } \\
2\end{array}$ & \\
\hline 1 & Isi & 86,6 & $\begin{array}{l}75, \\
5\end{array}$ & $\begin{array}{l}81,0 \\
5\end{array}$ & Valid \\
\hline 2 & Minat & 86,6 & $\begin{array}{l}73, \\
3\end{array}$ & 79,9 & Valid \\
\hline 3 & Bahas & 80 & 80 & 80 & Valid \\
\hline
\end{tabular}




\begin{tabular}{|l|l|l|l|l|}
\hline a & & & & \\
\hline $\begin{array}{l}\text { Rata- } \\
\text { rata }\end{array}$ & $\mathbf{8 4 , 4}$ & $\begin{array}{l}\mathbf{7 6}, \\
\mathbf{2 6}\end{array}$ & $\begin{array}{l}\mathbf{8 0 , 3} \\
\mathbf{1}\end{array}$ & Valid \\
\hline
\end{tabular}

$\mathrm{V} 1=$ validator $1, \mathrm{~V} 2=$ validator 2

Dari tabel di atas dapat diambil rata-rata dari aspek isi dan minat yaitu $80,31 \%$ dengan kategori valid.

Pada tabel hasil Validasi Desain

\begin{tabular}{|c|c|c|c|c|c|c|}
\hline \multirow[t]{2}{*}{ No } & \multirow{2}{*}{$\begin{array}{l}\text { Aspek } \\
\text { penilaia } \\
\mathrm{n}\end{array}$} & \multicolumn{4}{|c|}{$\begin{array}{l}\text { Persentase } \\
\text { penilaian }\end{array}$} & \multirow[t]{2}{*}{$\begin{array}{l}\text { Kateg } \\
\text { ori }\end{array}$} \\
\hline & & V1 & $\mathrm{V} 2$ & V3 & $\begin{array}{l}\text { Rata } \\
2\end{array}$ & \\
\hline 1 & Media & 80 & 94 & 84 & 88 & Valid \\
\hline 2 & Bahasa & 80 & 90 & 80 & 83,3 & Valid \\
\hline & Rata-rata & 80 & 92 & 82 & 85,6 & Valid \\
\hline
\end{tabular}

$\mathrm{V} 1=$ Validator $1, \mathrm{~V} 2=$ Validator 2, V3= Validator 3

Dari validasi yang dilihat dari aspke media dan bahasa didapatkan rata-rata validasi desain yaitu $88 \%$ dengan kategori sangat valid. Dari tabel diatas dapat diambil rata-rata keseluruhan validasi media pembelajaran multimedia interktif berbasis mobile yaitu $85,6 \%$ sehingga dapat disimpulkan media pembelajaran multimedia interaktif berbasis mobile tersebut termasuk pada kategori "valid" (lihat lampiran)

\section{Analisis Data}

\section{Data Uji Praktikalitas}

Data uji praktikalitas multimedia interaktif secara online pada mata kuliah bahasa pemograman I diambil dari angket yang telah dibagikan pada mahasiswa.

a. Data uji praktikalitas berdasarkan respon mahasiswa

Untuk praktikalitas media juga memerlukan masukan berupa respon mahasiswa. Data ini didapatkan setelah dilakukan pembelajaran, melalui angket yang diberikan kepada peserta didik, hasil yang didapatkan sebagaimana terlihat pada tabel dibawah ini:

\begin{tabular}{|c|c|c|c|}
\hline No & Aspek yang dinilai & $\%$ & Ket \\
\hline 1 & $\begin{array}{lr}\text { Saya } & \text { dapat } \\
\text { mengoperasikan } \\
\text { multiedia } & \text { interaktif } \\
\text { secara } & \text { online } \\
\text { dengan } & \text { sangat } \\
\text { mudah } & \end{array}$ & 80 & $\begin{array}{l}\text { Sangat } \\
\text { praktis }\end{array}$ \\
\hline 2 & \begin{tabular}{lr}
\multicolumn{2}{l}{ Dengan multimedia } \\
interaktif saya dapat \\
belajar rendiri \\
meskipun ranpa \\
dosen
\end{tabular} & 77,8 & $\begin{array}{l}\text { Sangat } \\
\text { Praktis }\end{array}$ \\
\hline 3 & \begin{tabular}{ll}
\multicolumn{2}{l}{ Dengan multimedia } \\
interiaktif & secara \\
online & \\
pembelajaran & \\
menjadi & lebih \\
praktis &
\end{tabular} & 81,1 & $\begin{array}{l}\text { Sangat } \\
\text { praktis }\end{array}$ \\
\hline 4 & $\begin{array}{lr}\text { Saya } & \text { dapat } \\
\text { memahami materi } \\
\text { pemebelajaran } \\
\text { dengan mudah } \\
\text { melalui multimedia } \\
\text { interiaktif secara } \\
\text { online }\end{array}$ & 82,2 & $\begin{array}{l}\text { Sangat } \\
\text { praktis }\end{array}$ \\
\hline 5 & $\begin{array}{lr}\text { multimedia } & \\
\text { interiaktif } & \text { secara } \\
\text { online } & \text { sangat } \\
\text { membantu r saya } \\
\text { dalam memahami } \\
\text { konsep r materi } \\
\text { pembelajaran }\end{array}$ & 81,1 & $\begin{array}{l}\text { Sangat } \\
\text { praktis }\end{array}$ \\
\hline 6 & $\begin{array}{l}\text { dengan multimedia } \\
\text { interiaktif secara } \\
\text { online saya dapat } \\
\text { memehami konsep } \\
\text { materi } \\
\text { pembelajaran dalam } \\
\text { waktu singkat }\end{array}$ & 81,1 & $\begin{array}{l}\text { Sangat } \\
\text { praktis }\end{array}$ \\
\hline 7 & $\begin{array}{lr}\text { saya lebih } & \text { cepat } \\
\text { memahami } & \text { materi } \\
\text { pelajaran } & \text { jika }\end{array}$ & 78 & $\begin{array}{l}\text { Sangat } \\
\text { praktis }\end{array}$ \\
\hline
\end{tabular}




\begin{tabular}{|c|c|c|c|}
\hline & $\begin{array}{l}\text { menggunakan } \\
\text { multimedia } \\
\text { interiaktif secara } \\
\text { online }\end{array}$ & & \\
\hline 8 & $\begin{array}{l}\text { saya menyenangi } \\
\text { pembelajaran } \\
\text { dengan multimedia } \\
\text { interiaktif secara } \\
\text { online }\end{array}$ & 81,1 & $\begin{array}{l}\text { Sangat } \\
\text { praktis }\end{array}$ \\
\hline 9 & $\begin{array}{l}\text { belajar dengan } \\
\text { multimedia } \\
\text { interiaktif secara } \\
\text { online } \\
\text { membangkitkan } \\
\text { minat saya untuk } \\
\text { lebih giat belajar }\end{array}$ & 82 & $\begin{array}{l}\text { Sangat } \\
\text { praktis }\end{array}$ \\
\hline 10 & $\begin{array}{l}\text { saya merasa tidak } \\
\text { bosan menjawab } \\
\text { pertanyaan } \\
\text { menggunakan } \\
\text { multimedia } \\
\text { interiaktif secara } \\
\text { online walaupun } \\
\text { dalam waktu yag } \\
\text { lama }\end{array}$ & 78 & $\begin{array}{l}\text { Sangat } \\
\text { Praktis }\end{array}$ \\
\hline 11 & $\begin{array}{l}\text { gambar, animasi, } \\
\text { dan video secara } \\
\text { online } \\
\text { memudahkan saya } \\
\text { memperoleh } \\
\text { pengalaman belajar } \\
\text { secara nyata }\end{array}$ & 79 & $\begin{array}{l}\text { Sangat } \\
\text { praktis }\end{array}$ \\
\hline 12 & $\begin{array}{l}\text { Saya dapat } \\
\text { berkonsentrasi/ } \\
\text { fokus mengerjakan } \\
\text { kegiatan yang ada } \\
\text { di dalamnya }\end{array}$ & 81 & $\begin{array}{l}\text { Sangat } \\
\text { praktis }\end{array}$ \\
\hline
\end{tabular}

Data diatas direkap dan disederhanakan sesuai dengan kisi praktikalitas seperti terlihat pada tabel dibawah ini”"

\begin{tabular}{|l|l|l|l|}
\hline No & Aspek penilaian & $\begin{array}{l}\text { Persentas } \\
\text { e }\end{array}$ & $\begin{array}{l}\text { Kategor } \\
\text { i }\end{array}$ \\
\hline
\end{tabular}

\begin{tabular}{|l|l|l|l|}
\hline 1 & $\begin{array}{l}\text { Kemudahan } \\
\text { penggunaan media }\end{array}$ & 80,44 & Praktis \\
\hline 2 & $\begin{array}{l}\text { Tampilan dan daya } \\
\text { tarik media }\end{array}$ & 79,44 & Praktis \\
\hline 3 & Efesiensi waktu & 80,22 & Praktis \\
\hline & Rata-rata & $\mathbf{8 0 , 0 4}$ & Praktis \\
\hline
\end{tabular}

Dari rabel ditas diperoleh rata-rata rekapitulasi dilihat dari aspke kemudahan penggunanan media, tampilan dan data tarik media dan efesiensi waktu adalah 80,04\% dengan kategori : Praktis", (lihat lampiran)

\section{Data Uji Efektivitas}

Sebelum melakukan tes terlebih dahulu dilakukan uji validitas, reliabilitas, dan indeks daya beda terhadap soal yang akan diujikan berdasarka perhitungan SPSS diperoleh 25 butir soal valid dan 5 soal tidak valid dari 30 soal yang diujicobakan. Sedangkan reliabilitas soal diperoleh skor Cronbach's Alpha sebesar 0,739 dengan interprestasu reliabiltas tinggi. Untuk lebih jelas dari hasil uji reliabilitas dapat dilihat pada lampiran 15 . Sedangkan dari hasil perhitungan indeks kesukaran soal tes yang dilakukan pada 30 soal uji coba maka diperoleh 4 soal pada klafikasi mudah, 2 soal sukar dan 24 soal pada klasikfikasi sedang. Hasil analisis tingkat kesuakaran soal dapt dilihat pada lampiran 16.

Hasil uji efektivitas diperoleh melalui tes kepada siswa sebelum dan setelah melakukan pembelajaran dengan menggunakan media pembelajaran multimedia interaktif berbasis mobile, yaitu dengan mengerjakan 25 soal tes objektif (lampiran)

Hasil uji t untuk pre-test dan posttest didapatkan bahwa penerapan media pembelajaran multimedia interaktif berbasis mobile berpengaruh signifikan terhadap hasil belajar yaitu $0,001<0,05$. Hasil ini telah memberikan kesimpulan bahwa media pembelajaran multimedia interaktif berbasis mobile berada pada 
kriteria efektif untuk digunakan padamata kuliah Bahasa Pemograman I

\section{Pembahasan}

Pembelajaran yang menggunakan teknologi informasi dan komunikasi atau menggunakan multimedia disebut dengan medai pembelajaran multimedia interaktif berbasis mobile. Penggunaan media pembelajaran ini dimaksudkan untuk membantu pendidik dalam menyampaikan materi dan juga membantu pesertadidik dalam memahami materi yang diajarkan. Mobile Learning adalah model pembelajaran yang multimedia interaktif yang dapat mengakses materi pembelajaran yang memiliki karakter yang tidak tergantung waktu dan lokasi dimana dan kapan saja yang mampu meningkatkan motivasi belajar mahasiswa karena mobile learning memberikan kesempatan melakukan kolaborasi dengan melaksanakan interaksi antara dan mahasiswa karena model alternatif mampu menyediakan fasilitas knowledge sharing dan visualisasi pengetahuan menjadi lebih menarik dan mudah dipahami sehingga akan terwujudnya suasana pembelajaran interaktif berbasis mobile learning. Artinya, proses pembelajaran dengan fasiltas lebih menarik dengan melengkapi vedio, text dan grafik yang bersifat interaktif dan tujuan pembelajaran dapat dicapai secara optimal.Mobile learning (m-learning) adalah pembelajaran yang memanfaatkan teknologi dan perangkat mobile. Dalam hal ini, perangkat tersebut dapat berupa PDA, telepon seluler, laptop, tablet PC, dan sebagainya.

Pengembangan media pembelajaran multimedia interaktif berbasis mobile pada mata kuliah bahasa pemograman I dilakukan menggunakan aplikasi Visual Basic.Net yang memungkinkan untuk melengkapi media dengan sound serta animasi yang mampu mendukung penyajian materi serta menarik perhatian mahasiswa. Media pembelajaran multimedia interaktif berbasis mobile dikembangkan dengan berbasis komputer.
Ada serangkaian proses atau kegiatan yang dilakukan untuk menghasilkan media pembelajaran multimedia interaktif secara online yang valid, praktis, dan efektif. Model pengembangan multimedia interaktif secara online ini menggunakan model Addie (Analysis-Design-DevelopImplement-Evaluate) yang meliputi tiga tahap yaitu Analis (define), develope, dan evaluate.Berikut pembahasan masingmasing tahap pengembangan multimedia interaktif yang dikembangkan:

Tahap define

Pada tahap ini dilakukan analisis kebutuhan multimedia interaktif berbasis mobile yang terdiri dari analisis kurikulum dan media yang digunakan serta konsep materi pelajaran. Tujuan dalam tahapan ini adalah menentukan masalah dasar yang dibutuhkan dalam pengembangan media pembelajaran multimedia interaktif berbasis mobile. secara online dengan melakukan analisis kurikulum mempermudah penusunan alur pembelajaran bagi penguasaan konsep melakukan Visual Basic.Net, sehingga media yang dikembangkan ini benar-benar efektif dalam mencapai tujuan pembelajaran. Ibrahim (2003) menyatakan kurikulum yang berlaku secara nasional di Indonesia berorientasi pada tujuan. Pemanfaatan media dalam proses pembelajaran memberikan hasil yang memuaskan, karena karakteristik, kecakapan dasar spesifik dan gaya belajara yang dimiliki oleh mahasiswa Manajemen Informatika mendukung dalam pemanfaatan media pembelajaran yang digunakan dalam proses pembelajaran dengan menggunakan teknologi komputer.

\section{Tahap develop}

Tahap ini dilakukan pengembangan pada produk yang akan dirancang. Adapun perancangan yang dilakukan adalah sebagi berikut:
a. Perancangan Visual Basic.Net 
Multimedia interaktif dirancang dengan mempertimbangkan isi dan desain yang terkandung didalamnya. Pada isi, multimedia interaktif berbasis mobile disesuaikan dengan kurikulum, silabus yang ada pada mata kuliah bahasa pemograman I. Sedangkan desain media pembelajaran multimedia interaktif berbasis mobile dipertimbangkan pada aspek tampilan media dan bahasa yang ada pada multimedia interaktif berbasis mobile yang dikembangkan. Setelah media pembelajaran multimedia interaktif berbasis mobile dibuat maka selanjutya dilakukan tahap validasi terhadap pakar yang bertujuan untuk menentukan layak atau tidaknya media pembelajaran multimedia interaktif berbasis mobile tersebut.

b. Validasi media pembelajaran multimedia interaktif berbasis mobile

Validasi dilakukan pada penilaian ini menekankan pada validitas desain media dan isi atau materi. Validasi materi disini dinyatakan valid oleh validator karena media pembelajaran multimedia interaktif berbasis mobile yang dikembangkan telah sesuai dengan materi perkuliahan bahasa pemograman I.

Hasil validasi media pembelajaran multimedia interaktif secara online diperoleh dari tanggapan kembali dan oleh validator pada materi mendiangnosa permasalahan pengoperasian kemudian dihasilkan telah teruji dan telah dinyatakan valid oleh validator. Valid menurut Trianto (2010:225) adalah penilaian sudah memberikan informasi yang akurat tentang media yang dikembangkan. Hasil validasi terhadap media pembelajaran multimedia interaktif berbasis mobile dilakukan oleh tiga orang dosen STAIN Batusangkar sebagai validator desain media yang berpengalaman mengajar mata kuliah Bahasa Pemrograman I sebagai validator isi/materi media. Kelima validator merupakan ahli dalam bidang kajiannya, oleh sebab itu hasil validasi ini telah dapat dipertanggung jawabkan.

Media pembelajaran multimedia interaktif berbasis mobile yang dikembangkan sudah memenuhi aspek isi atau materi dengan nilai presentase rata-rata $80,31 \%$. Sedangkan aspek desain media pembelajaran multimedia interaktif berbasis mobile ini nilai persentase rata-rata $85,6 \%$. Kedua aspek tersebut apabila dijumlahkan skor nilai validitas yang diperoleh masing-masing validator maka didapatkan nilai persentase ratarata validasi adalah $82,95 \%$. Nilai yang diperoleh ini berada pada kategori tingkat kevalidan valid.

Secara isi media pembelajaran multimedia interaktif berbasis mobile, validator menyatakan bahwa media pembelajaran multimedia interaktif berbasis mobile yang dikembangkan sebagai salah satu media pembelajaran telah sesuai dengan kurikulum dan minat mahasiswa. Nilai validasi isi media yang dikembangkan didapatkan nilai persentase rata-rata $88 \%$ dengan kategori sangat valid. Validasi isi merupakan syarat yang berkenaan dengan proses menentukan konsepkonsep yang benar dan sesuai dengan kurikulum yang berlaku. Tingginya hasil validasi untuk validasi isi menandakan bahwa media pembelajaran multimedia interaktif berbasis mobile yang dikembangkan telah sangat sesuai dengan kurikulum yang digunakan saat ini.

Dari uraian hasil validasi aspek media dan aspek isi atau materi, maka media pembelajaran multimedia interaktif berbasis mobile yang dikembangkan sebagai media pembelajaran multimedia interaktif berbasi mobile pada mata kuliah bahasa pemograman I dinyatakan valid. Mesikupun hasil valid menunjukkan kriteria valid, namun 
media pembelajaran multimedia interaktif berbasis mobile ini belum sempurna, oleh karena itu validator memberikan beberapan saran untuk perbaikan. Berdasarkan rekomendari dari validator tersebut media pembelajaran multimedia interaktif berbasis mobile direvisi, sehingga media pembelajran multimedia interaktif berbasis mobile layak digunakan dan diujicobakan untuk pembelajaran. Hal ini sesuai dengan pendapat Akker (91999:127) komponen bahan pada prosuk yang dikembangkan harus didasarkan dengan konsisten satu sama lainnya (validitas konstruk), bila prosuk yang dikembangkan telah memenuhi persyaratan tersebut maka dianggap valid.

\section{Tahap Evaluate}

a. Kepraktisan media pembelajaran multimedia interaktif secara online

Data kepratisan media diambil melalui uji coba yang dilakukan di STAIN Batusangkar pada mahaiswa manajemen informatika. Uji coba ini bertujuan untuk melihat pelaksanaan pembelajaran dengan menggunakan multimedia interaktif berbasis mobile. Dalam proses ujicoba, peneliti dibantu oleh dua orang dosen produktif.

Penilaian terhadap kepraktisan media diperoleh dari angket yang diisi oleh dosen/praktisi. Hasil dari analisi angket dari dosen bahwa media pembelajaran multimedia interaktif berbasis mobile mata kuliah bahasa pemograman I dikategorikan praktis dalam penggunanannya pada proses pembelajaran. Ini berati bahwa medai pembelajaran multimedia interaktif berbasis mobile yang dikembangakan dapat membantu dosen dalam memberikan penjelasan yang benar terhadap konsep-konsep materi pembelajaran kepada peserta didik khususnya pada materi bahasa pemograman I.
Dari aspek waktu yang digunakan dalam pelaksanaanya, media pembelajaran multimedia interaktif berbasis mobile ini dikategorikan sangat praktis. Ini berarti media ini dapat membantu dosen untuk mengalokasikan waktu untuk menyampaikan materi pembelajaran sesuai dengan kurikulum. Media pembelajaran multimedia interaktif berbasis mobile yang dikembangkan memiliki nilai interprestasi yang baik sehingga mudah dipahami oleh dosen yang menggunakan media pembelajaran multimedia interaktif berbasis mobile tersebut. Selain itu, media pembelajaran multimedia interaktif berbasis mobile ini juga memiliki ekivalensi yang sangat baik sehingga dapat dijadikan pedoman oleh dosen dalam membuat dan merancang media pembelajaran baik sesuai dengan tuntutan kurikulum. Menurut trianto (2010:223)" keuntungan media pembelajaran salah satunya menimbulkan persepsi akan sebuah konsep yang sama.

Hasil analisis data angket respon mahasiswa mengenai media interaktif berbasis mobile tergolong sangat praktis, hal ini menunjukkan bahwa secara keseluruhan media pembelajaran multimedia interaktif berbasis mobile ini disenangi dan bisa dimengerti oleh mahasiswa. mahasiswa termotivasi oleh gambar, video, dan gambar animasi yang terdapat dalam media pembelajaran multimedia interaktif. Hasil analisis praktikalitas oleh tanggapan mahasiswa melalui angket dan hasil penilaian dapat dilihat pada tabel di atas. Berdasarkan data pada tabel tersebut diketaui pada aspek kemudahan penggunakan media diperoleh persentase rata-rata $88 \%$, aspek tampilan dan daya tarik media diperoleh rata-rata $83,3 \%$ dengan persentase rata-rata keseluruhan yaitu $85,6 \%$. Sehingga dapat disimpulkan 
bahwa multimedia interaktif berbasis mobile yang dikembangkan dikategorikan t praktis(lihat lampiran). b. Efektivitas media pembelajaran multimedia interaktif berbasis mobile.

Dari uraian diatas menunjukkan bahwa penggunaan media pembelajaran multimedia interaktif berbasis mobile yang dikembangkan memudahkan mahasiswa dalam memahami materi sehingga hasil belajar mahasiswa menjadi lebih baik. Seperti yang dikemukanan Harun Rasyid dan Mansyur (2007:03) evaluasi adalah proses penentuan sejauh mana proses pembelajaran telah tercapai. Hasil belajar diperoleh dari tes yang diberikan dalam bentuk tes objektif, tes objektif sebanyak 25 butir soal. Menurut Trianto (2010:235)" tes hasil belajar merupakan 30 butir tes yang digunakan untuk mengetahui hasil belajar mahasiswa setelah mengikuti kegiatan pembelajaran". Setelah hasil belajar siswa diperoleh, kemudian hasil tes tersebut dibandingkan dengan nilai akhir yang bisa dikatakan lulus, sehingga akan diperoleh gambaran pencapaian ketuntasan siswa secra individu. Hal ini sesuai dengan pendapat Trianto,:kriteria ketuntasan minimal adalah kiriteria ketuntasan belajar yang ditentukan oleh satuan pendidikan (masing-masing sekolah)". Berdasarkan hasil tes untuk pembelajaranmendiagnosis

permasalahan komputer menunjukkan bahwa dari 18 orang mahasiswa yang mengikuti tes setalah mereka menggunakan media pembelajaran multimedia interaktif berbasis mobile diperoleh 16 orang yang mendapat nilai tuntas, hal ini berarti 9 orang mahsiswa yang belum tuntas. Hal ini meningkat $\quad 42,11 \% \quad$ sebelum menggunakan multimedia interaktif berbasis mobile. hal ini menunjukkan bahwa adanya peningkatan hasil belajar mahasiswa sebelum menggunakan media pembelajran multimedia interaktif berbasis mobile dengan setelah menggunakan media pembelajaran multimedia interaktif. selain itu selama dalam proses uji coba berlangsung aktivitas siswa meningkat dari pertemuan awal sampai akhir. Media ini menarik perhatian, mahasiswa sangat antusias dalam mengikuti pembelajaran yang mengakibatkan hasil belajar mahasiswa meningkat. Sehingga disimpulkan bahwa pembelajaran menggunakan media pembelajaran multimedia interaktif dapat dikatakan efektif dalam meningkatkan hasil belajar mahasiswa.

\section{KESIMPULAN}

1. Adapun tahapan ADDIE adalah sebagai berikut: (a) tahap define yaitu pada tahap ini dilakukan beberapa analisis, dimulai dari analisis kurikulum sampai pada analisis konsep. (b) tahap develop yaitu tahapan dimana pengembangan media dilakukan. Pada tahapan ini dilakukan perancangan awal atau protoype media pembelajaran multimedia interaktif. perancangan media ini menggunakan aplikasi dreamwever dengan DBMS menggunakan XAMPP dengan bahasa pemrograman PHP. Setelah dilakukan perancangan, media yang sudah jadi diuji kevalidan oleh 5 orang validator masing-masing sebagai validator isi dan media. (c) tahap evaluate, setelah media pembelajaran multimedia interaktif berbasis mobile yang telah dirancang dikatakan valid maka dilakukan ujicoba produk dan kemudaian dihitung tingkat kepraktisan, efektivitasan media pembelajaran multimedia interaktif sehingga didapat media pembeljaran interaktif yang valid, praktis dan efektif.

2. Hasil pengembangan dari peneltian ini adalah berupa media pembelajaran multimedia interaktif berbasis mobile 
pada materi melakukan perbaikan peripheral yang dibuat menggunakan aplikasi dreamwever dengan DBMS menggunakan XAMPP dengan bahasa pemrograman PHP. Media ini dilengkapi dengan teks penjelasan materi, gambar, suara, video, gambar animasi untuk memercantik tampilan serta soal evaluasi. Sehingga siswa mudah memahami konsep dan mampu menarik perhatian dan minat belajar siswa. Media pembelajaran multimedia interaktif berbasis mobile ini dapat digunakan pada PC atau laptop, untuk menggunakan produk ini dapat dilakuakn tanpa menginstal program flash terlebih dahulu karena file utama disajikan dalam ekstensi (exe)

3. Hasil penelitian menunjukkan bahwa produk media pembelajaran multimedia interaktif berbasis mobile untuk matakuliah Bahasa Pemrograman I telah selesai dikembangkan dalam bentuk multimedia interaktif berbasis mobile sesuai dengan prosedur pengembangan. Secara umuum kualitas produk multimedia interaktif berbasis mobile ini termasuk dalam kriteria praktis dan efektif untuk digunakan. Berdasarkan hasil evaluasi ahli media dan isi atau materi bahwa media pembelajaran multimedia interaktif berbasis mobile ini layak dan teruji digunakan sebagai alternatif media pembelajaran multimedia interaktif berbasis matakuliah bahasa pemrograman I.

Berdasarkan kesimpulan dan temuan pada penelitian pengembangan multimedia interaktif berbasis mobile yang layak dan telah teruji memiliki implikasi yang tinggi dibandingkan dengan media pembelajaran buku teks atau media power point yang selama ini digunakan guru dalam proses pembelarajan. Adapun implikasinya adalah sebagai berikut:

1. Dengan demikian media pembeljaran multimedia interaktif dapat dijadikan bahan pertimbangan bagi guru dalam menyampaikan materi pelajaran agar lebih menarik.

2. Mobile learning (m-learning) adalah pembelajaran yang memanfaatkan teknologi dan perangkat mobile. Dalam hal ini, perangkat tersebut dapat berupa PDA, telepon seluler, laptop, tablet $\mathrm{PC}$, dan sebagainya

3. Mobile learning memberikan kesempatan melakukan kolaborasi dengan melaksanakan interaksi antara dan mahasiswa karena model alternatif mampu menyediakan fasilitas knowledge sharing dan visualisasi pengetahuan menjadi lebih menarik dan mudah dipahami.

4. Produk ini mampu memberi umpan balik yang lebih baik bagi mahasiswa.

\section{DAFTAR PUSTAKA}

Arsyad, Azhar. 2002. Media Pembelajaran. Jakarta: PT RajaGrafindo Persada.

Arsyad., Multimedia Interkatif Untuk Pembelajaran Multimedia Interkatif . Jakarta, (2002)

Azhar Arsyad. 2011. Media Pembelajaran. Jakarta : PT. Raja Grafindo Persad

Borg, W.R. dan Gall, M.D (1983). Educational Research An Intruction. New York: Longman

C, Quiin, M-Learning: Mobile , Wireless, In Your-Pocket Learning, http://linezine.com, diakses April 2016. 
Campbell, N.A., Reece, J. B. dan Mitchel. L., G (2002). Biologi Edisi Kelima-Jilid 1 .Jakarta: Erlangga

Cobine, D.R., 1997. Study With the Computer. ERUC diakses pada tanggal 22-10-2016 tersedia pada

Http://www.Ericfasility.net/eric digest/ed4500069.htm

Cornelius Trihendradi. (2009). Step by Step SPSS 16 Analisi Data Statistik. Yogyakarta: CV ANDI OFFSET

Darin E. Hartley, Selling elearning, American Society For Training and Development, 2001

Dick, W. \& Carey, L/ (1990). The Systenatic Design of Instruction Florida: Harper Collions Publisher.

Goh, (2009) Multiplatform ELearning Systems and Technologies: Mobile Devices for Ubiquitous ICT-Based Education. New York: Information science reference

Hasyim, Fuad. 2002 .Mobile Learning Menggagas SocioPreneurship Berbasis Teknologi Demi Kemajuan Pendidikan Purworejo dan Indonesia (online) http://dppm. uii.ac.id dokumen dikti files dpp, uii 05/39/44 paper lustrum xi final.pdf.html. Diakses 1 November 2012

Hasyim, Fuad. 2002 .Mobile Learning Menggagas SocioPreneurship Berbasis Teknologi Demi Kemajuan Pendidikan Purworejo dan Indonesia (online) http://dppm. uii.ac.id dokumen dikti files dpp, uii 05/39/44 paper lustrum xi final.pdf.html. Diakses 10 November 2016.

Iskandar. 2008. Metodologi Penelitian Pendidikan dan Sosial (Kuantitatif dan Kualitatif). Jakarta: GP Press.

Komara, E. 2014. Belajar dan Pembelajaran Interaktif. PT Refika Aditama. Bandung.

Koran, Jaya Kumar C (2002), Aplikasi E-Learning dalam pengajaran dan pembelajaran di Sekolah malaysia 